\title{
THE POLITICAL AND ECONOMIC RESULTS OF DECEMBER 2013
}

\author{
S.Zhavoronkov
}

In December, the Russian authorities made several symbolic gestures designed to sway public opinion both at home and abroad in favor of their policies. Thus, they pardoned Michail Khodorkovsky, Russia's number one political prisoner, and declared a large-scale amnesty marking the 20th anniversary of the Russian Constitution. The amnesty could be applied to some of the defendants in the so-called Bolotnaya Square Riots case initiated in the aftermath of the Moscow street protests of May 2012. The same conciliatory trend can be detected in Vladimir Putin's annual Presidential Address to the Federal Assembly. The address did not contain any political ideas (although Putin's proposal that that the powers of local self-government bodies should be clarified was rather alarming because all the previous clarifications of that kind had inevitably led to curbing the authority of those bodies). On the other hand, the Presidential Address contained a number of proposals concerning economic issues. Some of them were rather radical. Thus, the President promised that companies registered in offshore tax havens would be denied access to government procurement contracts and state guarantees. Also he promised tax holidays to 'new small businesses working in the manufacturing, social or scientific sectors', and called for tax breaks and improved investment conditions in Siberia. As far as the Near Abroad is concerned, Russia lavished Ukraine with a bailout package worth at least $\$ 20 \mathrm{bn}$, seen as a quid pro quo for the suspension, by Kiev, of signing the Association Agreement with the EU.

December 2013 was crowded with notable events. The most important event of the month was the release of Russia's number one political prisoner, former oil tycoon Michail Khodorkovsky. In late December, Vladimir Putin announced that Khodorkovsky had submitted an appeal for pardon and that he, Putin, was planning to pardon Khodorkovsky on humanitarian grounds. On the following day, Khodorkovsky was released from prison and immediately left for Germany. In his first interview given after having been released from jail, Khodorkovsky said that he was currently unable to return to Russia, that he was not going to go into politics, and that he had no plans to return to business. Instead, he promised to devote himself to (unspecified) social work. In this case he will, most likely, continue writing philosophical articles that are never focused on acute political issues, as he has been doing for a number of years. It is still an open question whether or not Khodorkovsky actually admitted his guilt. Putin's press secretary, Dmitry Peskov, insists that an appeal for pardon automatically implies an admission of guilt; Khodorkovsky denies this, while Russian legislation offers no definite answer to that question. A few more words about the circumstances of Khodarkovsky's pardon: his second jail term would have been over in less than six months; no new criminal proceedings had been initiated against him; and rumors of his imminent release had long been circulating among political commentators. Some people close to Putin - for example, head of the state-owned VTB Bank Andrei Kostin - had insisted on his release. After
Khodarkovsky's arrest, the remaining assets of Yukos had been managed by Leonid Nevzlin and a group of high-ranking Yukos executives who had fled Russia (Nevzlin had prevented Rosneft from seizing some of Yukos foreign assets by winning cases against Rosneft in the UK and USA). Thus, the most that Khodarkovsky can hope for is to get back part of his stake in Yukos, once transferred by him to his partners. He will, however, never be able to get back all his property either in Russia or abroad. When behind bars, Khodorkovsky wrote a number of rather nebulous and vaguely democratic essays (for example, when being behind bars in 2003-2013, he never spoke publicly on any electoral issues). He financed several websites, a press service and the foreign-based Institute of Modern Russia, thus providing employment to a handful of opposition activists. So, the list of his political activities during that time is rather short. Since 2006, his business partners have never invested in politics, at least publicly. Of course there was a good reason for Russia's authoritarian regime to continue keeping Khodorkovsky in jail for the purpose of intimidating all malcontents. However, the Russian authorities did not succumb to this temptation and decided, instead, to improve their image abroad. As far as the intimidation of malcontents is concerned, Russia still has many other political prisoners, and the 'anti-extremism' articles of her Criminal Code envisage heavy penalties for the expression of views absolutely unrelated to violence, etc.

In December, the Russian authorities declared a relatively large-scale amnesty marking the $20^{\text {th }}$ anniversary 
of the Russian Constitution. Unlike the widely publicized and rather half-hearted business amnesty (it was not applied to most of the items of Article 159 (fraud) of the Criminal Code, but only to convictions under Articles 159.1 (credit fraud) and 159.4 (fraud in the sphere of entrepreneurial activities) introduced in January 2013, thus making the lion's share of businessmen jailed for business crimes not eligible for amnesty until charges against them are downgraded in a lengthy procedure, not necessarily with a happy ending; as a result, instead of 100,000 prisoners expected to be released, a little more than 1,000 convicts went free), this amnesty is planned on a relatively large scale. It covers almost 20,000 persons, including a number of political prisoners (convicted or tried for inciting mass unrest during the Moscow riots on 6 May 2012, but not for the use of violence against representatives of the state) or 'circumpolitical' prisoners ${ }^{1}$, such as the Pussy Riot band members and the crew of the Greenpeace ship Arctic Sunrise. The amnesty also extends to mothers of minor children, people who committed offences as minors, disabled persons, pensioners, persons who served in hot spots, convicted of non-violent crimes. The amnesty is definitely a step in the right direction, bearing in mind that Russia has a prison population of 800,000 people, most of whom were jailed for non-violent or minor offences. Regretfully, the amnesty is not applied to the (numerous) persons convicted under Article 228.1 of the Criminal Code (the illegal acquisition or keeping without the purpose of sale of narcotic means or psychotropic substances on a large scale).

However, the State Duma did not manage to refrain from yet another round of toughening Russia's repressive legislation. In December, it further hardened the severe penalties envisaged under the 'anti-extremist' Articles 280 and 282 of the RF Criminal Code. The State Duma also penalized the expression of separatist opinions, apparently bearing in mind the controversial proposal that the Muslim areas of the North Caucasus should be separated from Russia (this idea has a lot of supporters both in Russia and in the Caucasus).

In December, Vladimir Putin delivered his annual Presidential Address to the Federal Assembly. The Address placed very little emphasis on political matters and was mostly devoted to economic issues. Putin's reticence on political issues is a positive sign - indeed, legislation in the political sphere should not be changed on an annual basis. The latest noteworthy reforms in that field took place in 2012, and it is better for Rus-

1 The cases of the Pussy Riot punk collective members and the crew of the Greenpeace ship Arctic Sunrise can be called circumpolitical: in a number of developed countries, their actions would have been classified as criminal offences, although such cases would be treated much more lightly than in Russia. sia to wait for their results to become materialized, at least until the next presidential and legislative election cycle. Regretfully, Russia's legislators have not taken a timeout, and the ruling party continues to energetically introduce amendments to existing legislation, making it more and more complicated. Thus, in 2013, on the eve of a new cycle of regional and municipal elections, the State Duma adopted a number of laws banning elected officials and their relatives from owning financial assets abroad, notwithstanding the fact that Russian legislation does not contain a normative definition of such assets. It is outrageous that, every year, numerous fundamental amendments are haphazardly introduced to legislation. Here is an example of this devil-may-care attitude to legislation. On the eve of the release of the Presidential Address, a number of influential persons suggested that the rules on party registration and mayoral election should be radically changed. Fortunately, the 'reform' attempt has ended in failure. So far, so good. The only exception to this general trend was the mysterious ${ }^{2}$ reshuffling of Russia's judicial system, caused by the liquidation of arbitration courts. It should be noted in this connection that those courts had never been paragons of efficiency, being - at least with regard to important court cases - under the thumb of Russia's executive authoritieso. As far as this judicial reform is concerned, the main question is this: what will befall the judges of the Supreme Court of Arbitration, bearing in mind that many of them will not be included in the new composition of the Russian Supreme Court? At the same time, Putin's Presidential Address draws attention to the municipal field and the powers vested in municipal authorities - the sphere that is ripe politically for yet another round of power and property redistribution. As regards the municipal sphere, Vladimir Putin said that 'the most important task is to clarify the general principles of local self-government, develop strong, independent, financially sustainable local authorities'. It is planned that the fulfillment of this task will be completed by the end of 2014. The reason for this initiative is clear: the municipal authorities of Russia's big cities (except for Moscow and St Petersburg) are vested with considerable powers and are elected without any complicated 'filters'. The federal center has little leverage over big cities' municipal authorities, even when the mayors are elected indirectly by the city councils composed of municipal deputies belonging to the ruling party. Moreover, Putin now has a Sword of Damocles hanging over his head in the form of his unfulfilled promise to introduce direct mayoral elections throughout Russia, given by Mr.

2 The reason for this judicial reform is a riddle wrapped up in an enigma - if the Kremlin had wanted to replace the head of the Supreme Court of Arbitration or some of its judges, they would have certainly obeyed its order to retire. 
Putin in the course of his 2012 presidential campaign. Therefore, there is a danger that, while using the promise to create financially sustainable local authorities as a smoke screen, the Kremlin is going to introduce a model resembling the one that has been employed in Moscow during the past twenty years. Under this model, the real executive power and almost total control over budget money are vested in appointed officials (who control municipal construction, commerce, the housing and utilities sector, education, healthcare, etc.), while the elected bodies of local self-government are vested only with some negligible powers (like the right to lower marriageable age) and purely symbolic control over a tiny proportion of tax revenue (for example, $0.001 \%$ of personal income tax collected in the region).

The rest of the political portion of Vladimir Putin' Presidential Address contains nothing noteworthy, except for his pious wish 'that all draft laws [...] should pass a so-called initial public reading involving NGOs and other civil society institutions'. It should be pointed out that this proposal starkly contradicts the current practice (initiated by Vladimir Putin and the RF Government) of passing draft laws at once in their second and third readings, as it happened in the case of the draft law on reforming the Russian Academy of Sciences (adopted on 18 September 2013).

By contrast with the political portion of Vladimir Putin's Presidential Address, its social and economic portions contain a lot of innovative proposals (although some of them lack originality). As regards the healthcare sector, Putin said that Russia should create a system for independently appraising the quality of medical care. However, the existing procedure for the provision of medical services, tied to the 'principal place of residence' or - in case of sophisticated medical services - to the system of regional quotas, etc., is hardly reconcilable with the aforementioned task formulated by Putin. Only one 'innovative proposal' regarding medical care is unambiguous and clearly understandable: ' $[$...] beginning in 2015, all children and teenagers must have a yearly mandatory free medical check-up, while adults should undergo such an examination every three years'. At the same time, it can be noted that such health checks are already available to everybody (is there anything new under the sun?). As regards Putin's intention to make them mandatory, it is not clear what will be done in order to achieve this goal. President Putin's most radical proposals belong to the realm of education. In fact, they herald the abandonment of the current Russian university entrance system based on a standardized national final school exam (SNFSE). Thus, among other things, Vladimir Putin said: 'Instruction has already been given that, starting from the next academic year, a mandatory essay-based final exam will be introduced for graduat- ing high school students. The results of this exam will be taken into consideration alongside the National Final School Exam when applying to universities and other educational institutions'. As far as higher medical educational establishments are concerned, Putin said that volunteers 'who have spent several years working in healthcare institutions should have priority admission to medical schools'. The current Russian university entrance system based on a standardized national final school exam [SNFSE] has indeed been subjected to severe criticism because of its insufficient transparency at the regional and school levels. The SNFSE system's credibility has also been undermined by the fact that many higher educational establishments have abandoned it in favor of various olympiads' results as instruments for university admission selection. Under the best-case scenario, such olympiads play the role of entrance examinations; under the worst-case scenario, they lead to corruption in university admissions. However, it is not advisable to replace Russia's current university entrance system based on the SFNSE by something else without first thoroughly analyzing the possible alternatives to that system, and it is equally pointless to further complicate the university admission process. Regretfully, in his annual Presidential Address, Vladimir Putin indicated that in the nearest future 'we must settle the matter of mutual recognition of school diplomas within the CIS', although the quality of high school education in some of the CIS countries is hugely inferior to Russia's.

In his annual Presidential Address, Putin put forth a number of revolutionary ideas in the field of taxation. However, their revolutionarily was somewhat devaled by Putin's own admission that some of those ideas (regarding the fight against offshore tax avoidance and evasion) had already been put forward by him in his previous annual Presidential Address, but nothing significant had been achieved in that field since then. Vladimir Putin said: 'According to experts, last year Russian exports via offshore tax havens and semi-tax havens amounted to 111 billion dollars, which equals twenty percent of our exports. Half of the 50-billion-dollar Russian investment abroad went to offshore tax havens as well. These numbers stand for the drain of capital that should be working in Russia and direct losses for the national budget. [...] The companies registered in an offshore jurisdiction but legally owned by a Russian citizen as the ultimate beneficiary should pay taxes in line with the Russian regulations, with the tax amounts payable to the Russian budget. And we should think of a way to collect this money. [...] Companies registered in an offshore jurisdiction should not be entitled to state support, including loans from the Vneshekonombank and state guarantees. These companies should also be denied access to government procurement contracts. 
In other words, those who want to use all the benefits and government support and at the same time get their profits while working in Russia should get registered in the Russian jurisdiction.' It is common knowledge that even some of the biggest Russian state-owned companies, like Gazprom and Rosneft, have their branches in offshore tax havens or semi-tax havens. The term semitax haven, used by Vladimir Putin in his Address, applies to the developed countries where certain taxes, such as profit tax, are levied at a low or nominal rate (e.g. Switzerland and The Netherlands). Thus, although the idea that companies registered in offshore jurisdictions should be denied access to government procurement is definitely sound, it will require strong political will at the national level to actually transform this idea into reality. It is doubtful whether the required political will really exists in today's Russia. To succeed, the proposed crackdown on such companies should be very thoroughly planned, and every detail given meticulous attention (for example, if offshore companies are to be given the right to become subcontractors, this anti-tax avoidance measure will be hugely watered down). As far as the taxation of Russian-owned offshore companies is concerned, it should be said that Russian taxes can be legally levied on such companies only if the governments of the said offshore tax havens agree to provide RF tax authorities with relevant tax information. For example, the USA has managed to force on offshore jurisdictions a number of information exchange agreements. But it should be remembered that the USA accounts for $20 \%$ of global GDP, while Russia's share in global GDP amounts to just 3\%. Therefore Russia has much smaller leverage over offshore tax havens than that enjoyed by the USA.

At the same time, Vladimir Putin proposed the introduction of a number of tax exemptions, including tax holidays, less obviously beneficial to Russia's fiscal system. He suggested creating 'a network of special advanced economic development zones in the Far East and Eastern Siberia with special conditions for organizing non-extractive production'. According to Putin, new companies located in such zones should be granted five-year exemptions from income tax, mineral extraction tax (with the exception of oil and natural gas), and preferential insurance rates. Putin proposed that regions should be vested with the right to 'offer twoyear tax holidays to new small businesses working in the manufacturing, social or scientific sectors'. Bearing in mind that the upper limit of revenues set by the Russian government for small businesses is $\mathrm{Rb} 400 \mathrm{~m}$ (and such profits remain a pipe dream for any authentically small Russian business), this move can pose a serious threat to large-scale financial optimization. One can only hope that the RF Ministry of Finance, which has always objected to wholesale allocation of such benefits, will find some way to limit the size and scope of this emerging tax 'black hole', by issuing corresponding normative documents.

In December 2013, Russia lavished Ukraine with a huge bailout package, seen as a quid pro quo for the suspension, by Kiev, of signing the Association Agreement and a free trade pact with the EU. The price of Russian natural gas delivered to Ukraine was cut by almost half. Also, Russia promised to buy \$15bn worth of Ukrainian Eurobonds (the money would come from Russia's National Welfare Fund). But experts are wondering what Moscow is going to get in return... Ukraine has made no promises whatsoever to do anything in return for this gift - not even to abandon the idea of signing the Association Agreement with the EU. According to Ukrainian government statements intended to appeal to a domestic audience, the signing process was not cancelled but suspended. Moreover, two years from now Ukraine will hold a presidential election. It should be added that Victor Yanukovych's chance of re-election as president is rather slim - at the last general election, his party managed to win only $30 \%$ of the vote. One can easily draw some parallels between the current situation in Ukraine and the 2004 events in that country. In 2004, Russia tried to curry favor with Ukraine by signing a gas supply contract that contained some extremely favorable terms for the Ukrainian side. Then everything went awry for the Kremlin. A fateful presidential election was won by a 'wrong' person, who had snatched victory from the jaws of defeat. The 2004 Presidential Election brought a 'wrong' person to power. As the old proverb goes, history repeats itself. So, why cannot the 2004 situation repeat itself in 2015? In order to implement the December 2013 Agreement, Russia will have to rapidly change her legislation by adding the poor Ukraine (her per capita GDP based on the PPP methodology amounts to $\$ 7.3$ thousand, and her trade deficit is persistently high) to the list of the most developed countries whose government bonds are bought by Russia's National Welfare Fund. Meanwhile, the most reasonable resolution of Russian-Ukrainian contradiction would have been a cut in the price of Russian natural gas delivered to Ukraine, offered to that country not as a charitable donation, but as a quid pro quo for an increase in Ukraine's natural gas transit to Europe. It should be noted that this transit is relatively cheap (it is still hotly disputed whether or not gas transport by Nord Stream is cheaper than Ukraine's transit). At least for now, while Nord Stream is still operating below its full capacity, Ukraine's transit is cheaper that that by Nord Stream. And it is definitely cheaper than the cost of construction of the South Stream pipeline that will run through the bottom of the deep Black Sea. 